\title{
Regulation of steroid production in ovarian stromal tissue from 5- to 8-week-old pullets and laying hens
}

\author{
J. M. Levorse* and A. L. Johnson ${ }^{\dagger}$ \\ Department of Animal Sciences, Rutgers, The State University of New Jersey, New Brunswick, \\ NJ 08903, USA
}

\begin{abstract}
Studies were conducted to evaluate the regulation of steroid production in dispersed cells from ovarian stromal tissue from 5- to 8-week-old-pullets (IM cells) and laying hens (MAT cells). Short-term incubation of IM and MAT cells with ovine (o) LH resulted in a dose-dependent increase in progesterone, androstenedione and oestradiol production; progesterone production was greater in MAT cells than in IM cells $(P<0.05)$ in response to $2-200 \mathrm{ng} \mathrm{oLH} \mathrm{ml}^{-1}$, whereas androstenedione and oestradiol production was greater in MAT cells following treatment with 20 and $200 \mathrm{ng} \mathrm{oLH} \mathrm{ml}^{-1}(P<0.05)$. In both cell populations the cyclic adenosine monophosphate (cAMP) analogue, 8-bromo-cAMP ( 1 and $10 \mathrm{mmol} \mathrm{\textrm {l } ^ { - 1 }}$ ) stimulated progesterone and androstenedione production, whereas oLH $\left(200 \mathrm{ng} \mathrm{ml}^{-1}\right)$ and forskolin $\left(1-10 \mu \mathrm{mol} \mathrm{l}^{-1}\right)$ promoted cAMP accumulation $(P<0.05$ compared with basal values). However, treatment with the protein kinase $C$ activator, phorbol 12-myristate 13-acetate (PMA), did not alter basal or oLH-stimulated cAMP accumulation or progesterone production in either IM or MAT cells $(P>0.10)$. PMA did, however, inhibit agonist-induced androstenedione production $(P<0.05)$; co-treatment with the calcium ionophore A23187 potentiated this inhibitory effect. Finally, treatment with transforming growth factor- $\alpha$ (TGF- $\alpha ; 1.8-18$ pmol $1^{-1}$ ) did not affect basal or oLHstimulated progesterone or androstenedione production by IM cells, MAT cells, theca cells from 6-8 mm follicles or theca cells from the second largest (F2) follicle $(P>0.10)$. We conclude that LH-stimulated steroid production is greater in MAT cells than in IM cells; production of steroids at both stages occurs, at least in part, via the adenylyl cyclase/cyclic AMP second messenger pathway. However, we propose that activation of protein kinase $C$ can inhibit agonist-induced cytochrome P450 17 $\alpha$-hydroxylase, but not cytochrome P450 cholesterol side-chain cleavage, activity in stromal cells. Finally, steroidogenesis in stromal tissue from 5- to 8-week-old pullet and laying hen ovaries is regulated by hormonal and cellular mechanisms most comparable to those that modulate steroidogenesis in theca cells from 6- to $8-\mathrm{mm}$ and F2 follicles.
\end{abstract}

\section{Introduction}

Much work has been accomplished to characterize hormones and second messenger systems that regulate steroidogenesis in hen preovulatory follicles. The gonadotrophin LH stimulates steroid production in granulosa cells from the largest (F1) preovulatory follicle (Zakar and Hertelendy, 1980; reviewed by Johnson, 1990) and theca cells from the second largest preovulatory (F2) follicle (Tilly and Johnson, 1989a) via the cyclic $\mathrm{AMP} /$ protein kinase $\mathrm{A}$ second messenger system, and these actions depend on calcium mobilization (Asem and Hertelendy, 1986a, b, 1987; Asem et al., 1987;

\footnotetext{
*Present address: Department of Molecular Biology, Princeton University, Princeton, NJ 08544, USA

${ }^{\dagger}$ Corresponding author. Present address, Department of Biological Sciences, The University of Notre Dame, Notre Dame, IN 46556 USA.

Received 29 March 1993.
}

Levorse et al., 1991). Moreover, the diacylglycerol/protein kinase $C$ second messenger system modulates steroidogenesis in both granulosa and theca cells from preovulatory follicles (Tilly and Johnson, 1988, 1989a; Asem and Tsang, 1989); however, the endocrine/paracrine factors that affect protein kinase $C$ activation within preovulatory follicles have yet to be unequivocally identified. Finally, transforming growth factor- $\alpha$ (TGF- $\alpha$ ) and epidermal growth factor (EGF) can regulate steroidogenesis in granulosa cells from preovulatory follicles (Tilly and Johnson, 1990a), but the effects of these growth factors on theca cell steroid production from follicles at any stage of development have yet to be established.

Although preovulatory follicles contribute substantially to the total ovarian steroidogenic output, they represent the least numerous of the types of follicle present within the ovary. It has been demonstrated that ovarian follicies of less than $1 \mathrm{~mm}$ from laying hens produce steroids in response to 
incubation with LH (Robinson and Etches, 1986) as do whole ovaries from 1- to 28-day-old chicks (Marrone, 1986). When the mass of ovarian stromal tissue and the large number of primordial follicles within the ovary of both prepubertal and mature birds is considered, it is conceivable that these tissues provide a significant contribution to the total ovarian steroidogenic output. Nevertheless, little is known about the mechanisms that regulate steroidogenesis in ovarian stromal tissue. Thus, the following studies were conducted to characterize the second messenger systems that regulate steroid production in dispersed cells isolated from stromal tissue from both immature (5- to 8-week-old) and sexually mature birds. In addition, when published data were not available we compared cellular mechanisms that mediate steroid production in IM and MAT cells with those active in $6-8 \mathrm{~mm}$ follicle theca cells and F2 theca cells. Results of these studies indicate that, although stromal tissue from pullets generally has lower capacity to produce progesterone, androstenedione and oestradiol than does stromal tissue from mature ovaries, steroid production in both tissues is regulated by cellular mechanisms similar to those in theca (but not granulosa) cells of more mature (for example 6-8 mm and F2) follicles.

\section{Materials and Methods}

\section{Animals}

Single comb white Leghorn chickens (Avian Services, Frenchtown, NJ; or Moyer's Hatchery, Quakertown, PA) were used at 5-8 weeks of age (pullets) or at 35-50 weeks (laying hens). Pullets were housed in floor pens under a photoperiod of $11 \mathrm{~h}$ light:13 $\mathrm{h}$ dark (lights on at 08:00 h), while hens were housed individually in laying batteries under a $15 \mathrm{~h}$ light: $9 \mathrm{~h}$ dark photoperiod (lights on at 23:00 h). All birds had free access to feed (Broilermaker or Layer Mash, Agway, Inc., Bordentown, NI) and water. Individual laying records of hens were maintained daily by monitoring time of oviposition. Time of ovulation was predicted using previous laying records and by digital palpation on the day of an experiment. Birds were killed by cervical dislocation between 07:00 and 08:30 h (pullets), or 17-16 $\mathrm{h}$ before the second or third ovulation of a sequence (hens).

\section{Reagents}

Ovine (o) LH (NIAMDD-oLH-26) was provided by S. Raiti, National Hormone and Pituitary Program, NIH, Baltimore, MD. Eight-bromo-cyclic adenosine monophosphate (8-bromocAMP), 3-isobutyl-1-methylxanthine (IBMX), phorbol 12-myristate 13-acetate (PMA) and the calcium ionophore A23187 were obtained from Sigma Chemical Co. (St Louis, $\mathrm{MO}$ ). Forskolin was from Calbiochem (San Diego, CA), and human recombinant transforming growth factor- $\alpha$ (TGF- $\alpha$ ) and human recombinant epidermal growth factor (EGF) were from Bachem, Inc. (Torrance, CA). The growth factors TGF- $\alpha$ and EGF were prepared in advance from stock solutions ( $34 \mathrm{nmol} \mathrm{l}^{-1}$ and $16.4 \mu \mathrm{mol} \mathrm{l}^{-1}$, respectively) in incubation medium (see below), whereas 8-bromo cAMP was dissolved in incubation medium immediately before each experiment.
The phorbol ester PMA was prepared from a stock solution ( $1 \mathrm{mg} \mathrm{ml}{ }^{-1}$ ) in $95 \%$ ethanol, while stock solutions of forskolin $\left(0.05 \mathrm{~mol} \mathrm{l}^{-1}\right)$, IBMX $\left(1 \mathrm{~mol} \mathrm{l}^{-1}\right)$ and A23187 $\left(0.05 \mathrm{~mol} \mathrm{l}^{-1}\right)$ were prepared in dimethylsulfoxide (DMSO). In all instances the vehicle (final concentration of $0.1 \%$ or less) had no effect on the parameters measured (data not shown).

\section{Cell incubations}

Medium 199 with Hepes supplemented as previously described (M199/Hepes; Tilly and Johnson, 1987) was used as the incubation medium in all experiments. Ovaries were collected from two to six birds and transported to the laboratory in ice-cold $1 \%$ saline. Three different tissues were collected from ovaries of laying hens; the F2 follicle, 6-8-mm diameter follicles, and ovarian stromal tissue. Theca cells from the F2 follicle were dispersed and enriched by Percoll gradient as described by Tilly and Johnson (1989a), whereas theca cells from $6-8 \mathrm{~mm}$ follicles were prepared and enriched as described by Kowalski et al. (1991).

Dispersed cells were prepared from pullet and hen stromal tissue in a manner similar to the isolation of $F 2$ theca cells, with the following exceptions. After collection of pullet and hen ovaries and removing as many follicles as possible from the adult ovary (i.e. follicles greater than $4 \mathrm{~mm}$ ), the remaining stromal tissue was placed in the lid of a sterile $100 \mathrm{~mm}$ Petri dish and crushed with the bottom of the Petri dish. Tissue was placed in M199/Hepes containing $0.3 \%$ collagenase for $90 \mathrm{~min}$ at $39^{\circ} \mathrm{C}$, and was frequently triturated using a flamed-tip Pasteur pipette. Dispersed cells were centrifuged through a $50 \%$ continuous Percoll density gradient at $1800 \mathrm{~g}$ for $20 \mathrm{~min}$. The top $1 \mathrm{ml}$ of the gradient containing cell debris was discarded and fractions with densities between 1.037 and 1.058 were collected and pooled. These are the same fractions collected as for the F2 and 6-8 mm follicles (Tilly and Johnson, 1989a; Kowalski et al., 1991), and they were chosen to represent oLH-responsive cells in terms of androstenedione production (Levorse, 1992). After a wash in two volumes of fresh M199/Hepes, cells were centrifuged at $600 \mathrm{~g}$ for $15 \mathrm{~min}$ at room temperature, and then resuspended in fresh M199/ Hepes and counted in a haemocytometer. Cell incubations were carried out in $12 \mathrm{~mm} \times 75 \mathrm{~mm}$ polypropylene incubation tubes (Sarstedt, Princeton, NJ) in a final volume of $0.5 \mathrm{ml}$. All incubations were conducted at $39^{\circ} \mathrm{C}$ for $4 \mathrm{~h}$ under ambient air conditions.

\section{Experiments}

Experiment 1 was conducted to determine whether MAT cells and IM cells respond to oLH by a dose-dependent increase in steroid production. MAT or IM cells $\left(5 \times 10^{5}\right.$ cells per tube) were incubated with increasing doses $(0.2-200 \mathrm{ng}$ $\mathrm{ml}^{-1}$ ) of oLH. At the end of the incubation, cells were frozen at $-20^{\circ} \mathrm{C}$, and the cell plus medium content of progesterone, androstenedione and oestradiol was subsequently measured.

A second experiment was performed to compare progesterone and androstenedione production in MAT and IM cells following treatment with 8-bromo-cyclic AMP, an agent that stimulates steroid production at a site distal to the LH receptor. 
IM and MAT cells were incubated with increasing doses of 8-bromo-cAMP $\left(0.1-10 \mathrm{mmol}^{-1}\right)$ and subsequently assayed for progesterone and androstenedione.

The third experiment was conducted to evaluate further the role of the adenylyl cyclase/cyclic AMP second messenger system as a mediator of steroid production, and to compare the ability of MAT and IM cells to produce cAMP. Cells were incubated in the presence of oLH $\left(2-200 \mathrm{ng} \mathrm{ml}^{-1}\right)$ or forskolin (a stimulator of adenylyl cyclase activity; $0.1-10 \mu \mathrm{mol} \mathrm{l}^{-1}$ ). All incubations were conducted in the presence of the phosphodiesterase inhibitor, IBMX $\left(0.1 \mathrm{mmol} \mathrm{l}^{-1}\right)$. At the end of incubation, tubes were rapidly frozen to $-70^{\circ} \mathrm{C}$ until cells plus medium were assayed for cAMP.

The fourth experiment was designed to determine whether the diacylglycerol/protein kinase $C$ second messenger pathway modulates cAMP accumulation or steroidogenesis in MAT and IM cells. IM and MAT cells were incubated with $0.1 \mathrm{mmol}$ IBMX I- $\mathrm{I}^{-1}$ and increasing doses of oLH $\left(0.2-200 \mathrm{ng} \mathrm{ml}^{-1}\right)$ with and without $167 \mathrm{nmol}$ PMA $\mathrm{I}^{-1}$, and cAMP accumulation was measured. Cells were also incubated with PMA (3.3-167 nmol $\left.\mathrm{I}^{-1}\right)$ alone or in the presence of $20 \mathrm{ng} \mathrm{oLH} \mathrm{ml}^{-1}$ or $1 \mathrm{mmol} 8$-bromo cAMP I $^{-1}$ (for progesterone and androstenedione production). In addition, IM cells, MAT cells and theca cells from 6 to $8 \mathrm{~mm}$ follicles $\left(5 \times 10^{5}\right.$ cells per tube) were incubated with A23187 $\left(0.05-1 \mu \mathrm{mol} \mathrm{l}^{-1}\right)$ alone, in the presence of oLH $\left(20 \mathrm{ng} \mathrm{ml}^{-1}\right)$ or oLH plus PMA ( $167 \mathrm{nmol} \mathrm{l}^{-1}$ ). After incubation for $4 \mathrm{~h}$, cells plus medium were frozen at $-20^{\circ} \mathrm{C}$ until assayed for androstenedione.

The final experiment was conducted to determine whether the growth factors TGF- $\alpha$ or EGF modulate steroidogenesis in IM cells, MAT cells, 6-8 mm follicle theca cells or F2 follicle theca cells $\left(2 \times 10^{5}\right.$ cells per tube). Cells were incubated with TGF- $\alpha\left(1.8,6\right.$ or 18 pmol $\left.1^{-1}\right)$ or EGF (16, 41 or $164 \mathrm{nmol} \mathrm{l}^{-1}$ ), alone or in the presence of $20 \mathrm{ng} \mathrm{oLH} \mathrm{ml}{ }^{-1}$. Doses of these growth factors were chosen on the basis of results from previous studies (Tilly and Johnson, 1990a, b). After incubation, cells plus medium were frozen at $-20^{\circ} \mathrm{C}$ until assayed for progesterone and androstenedione.

\section{Radioimmunoassays}

Progesterone, androstenedione and oestradiol were measured by specific radioimmunoassay as described by Tilly and Johnson (1989a, b) and Tilly et al. (1991). The inter- and intra-assay coefficients of variation were $<15 \%$ for all steroid assays conducted. The radioimmunoassay for cyclic AMP was performed on succinylated samples, as described by Johnson and Tilly (1988). All samples within an experiment were measured in a single assay, and the resulting intra-assay coefficient of variation was less than $10 \%$.

\section{Data analysis}

Steroid production from F2 theca cells (Expt 5) was normalized to ng (androstenedione) or pg (progesterone) per 500000 cells. Data represent the mean \pm SEM of three to five replicate experiments. Treatment effects were determined by a one- or two-way analysis of variance, as appropriate. Significant
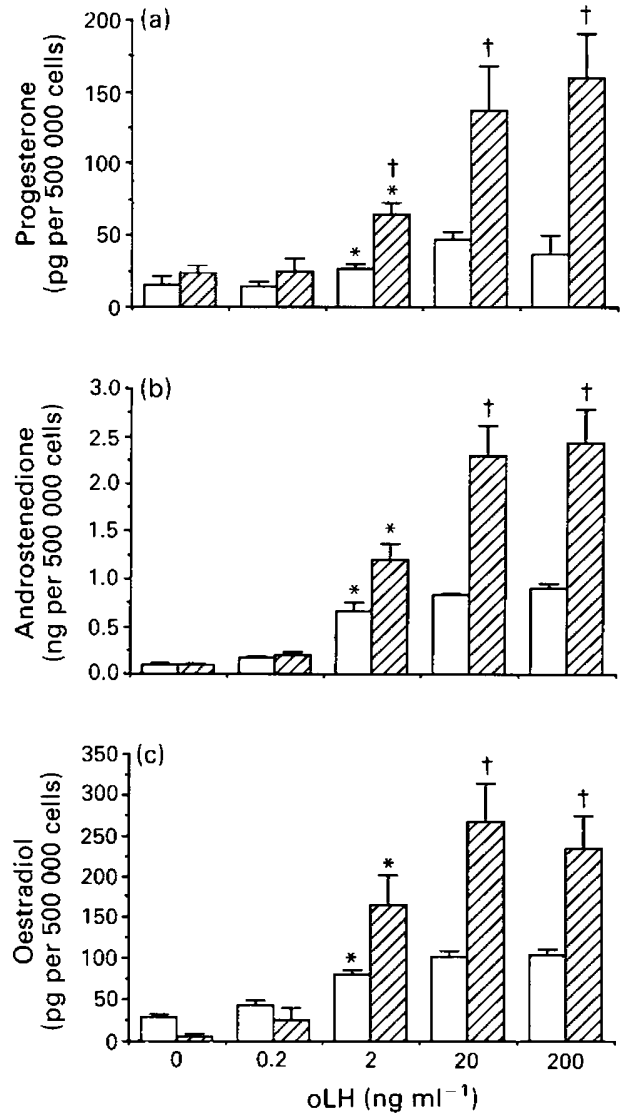

Fig. 1. Ovine (o) LH-induced (a) progesterone, (b) androstenedione and (c) oestradiol production by dispersed cells from ovarian stromal tissue collected from $(\square)$ pullets and $(\square)$ laying hens. Data represent the mean \pm SEM of four (pullets) or five (laying hens) replicate experiments. ${ }^{*}$ Denotes the lowest stimulatory dose of oLH $(P<0.05$ versus basal). ${ }^{\dagger}$ Denotes significant differences in steroid production between pullets and laying hens $(P<0.05)$.

differences $(P<0.05)$ were partitioned by the Newman-Keuls multiple range test.

\section{Results}

\section{Experiment 1: effects of oLH on steroid output}

Basal concentrations of progesterone, androstenedione and oestradiol were low, but detectable, in IM and MAT cells, and concentrations of each steroid increased following treatment with $2-200 \mathrm{ng}^{\mathrm{oLH} \mathrm{ml}}{ }^{-1}$ (Fig. 1). Progesterone production by MAT cells exceeded production by IM cells at 2-200 $\mathrm{ng} \mathrm{oLH} \mathrm{ml}{ }^{-1}$, whereas androstenedione and oestradiol production in MAT cells exceeded that from IM cells at 20 and $200 \mathrm{ng} \mathrm{oLH} \mathrm{ml}{ }^{-1}(P<0.05)$.

\section{Experiment 2: effects of 8-bromo cAMP on steroidogenesis}

Treatment with 1 and $10 \mathrm{mmol} 8$-bromo-cAMP $\mathrm{l}^{-1}$ significantly increased progesterone and androstenedione production 

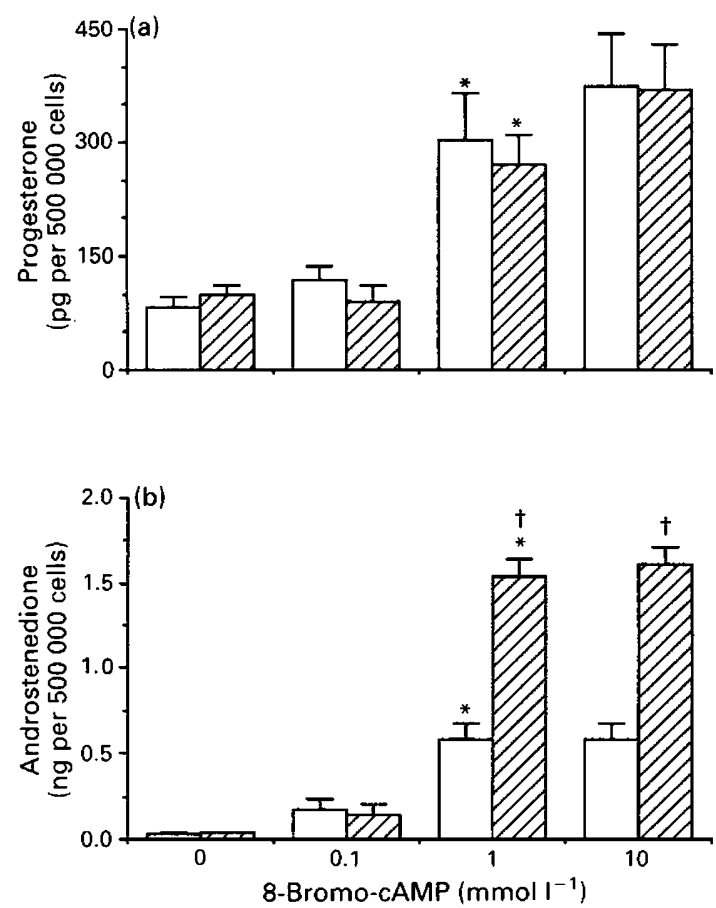

Fig. 2. 8-Bromo cAMP-induced (a) progesterone and (b) androstenedione production by dispersed ovarian stromal cells from $(\square)$ pullets and $(\Theta)$ laying hens. Data represent the mean \pm SEM from three replicate experiments. ${ }^{*}$ Denotes the lowest stimulatory dose of 8-bromo cAMP ( $P<0.05$ versus basal). ${ }^{\dagger}$ Denotes significant differences in androstenedione production between pullets and laying hens $(P<0.05)$.

in IM and MAT cells (Fig. 2). MAT cells produced higher concentrations of androstenedione in response to 8-bromocAMP than did IM cells $(P<0.05)$.

\section{Experiment 3: effects of oLH and forskolin on CAMP concentrations}

Incubation of IM and MAT cells with $200 \mathrm{ng} \mathrm{oLH} \mathrm{ml} \mathrm{m}^{-1}$ resulted in an increase in cAMP accumulation $(P<0.05$; Fig. 3, top panel); there was no significant difference in the amount of cAMP accumulation in IM versus MAT cells. Forskolin also stimulated cAMP accumulation; however, a significant increase in $\mathrm{IM}$ cells was detected at $0.1 \mu \mathrm{mol}$ forskolin $\mathrm{l}^{-1}$, while concentrations of CAMP in MAT cells increased after treatment with $1.0 \mu \mathrm{mol}$ forskolin $\mathrm{I}^{-1}(P<0.05)$.

\section{Experiment 4: effects of PMA on steroidogenesis}

Basal concentrations of cAMP were not different between MAT and IM cells (combined mean, $1.82 \pm 0.30 \mathrm{pmol} \mathrm{I}^{-1}$ per 500000 cells) and oLH enhanced accumulation of cAMP in MAT and IM cells in a dose-dependent fashion (2.09 \pm 1.28 , $3.89 \pm 0.41$ and $8.63 \pm 1.57$ pmol cAMP $1^{-1}$ for 2,20 and $200 \mathrm{ng} \mathrm{oLH} \mathrm{ml} \mathrm{I}^{-1}$, respectively). PMA treatment, however, had no significant effect on basal or oLH-stimulated concentrations of cAMP. Furthermore, PMA failed to alter significantly basal, or oLH- or 8-bromo-cAMP-induced progesterone
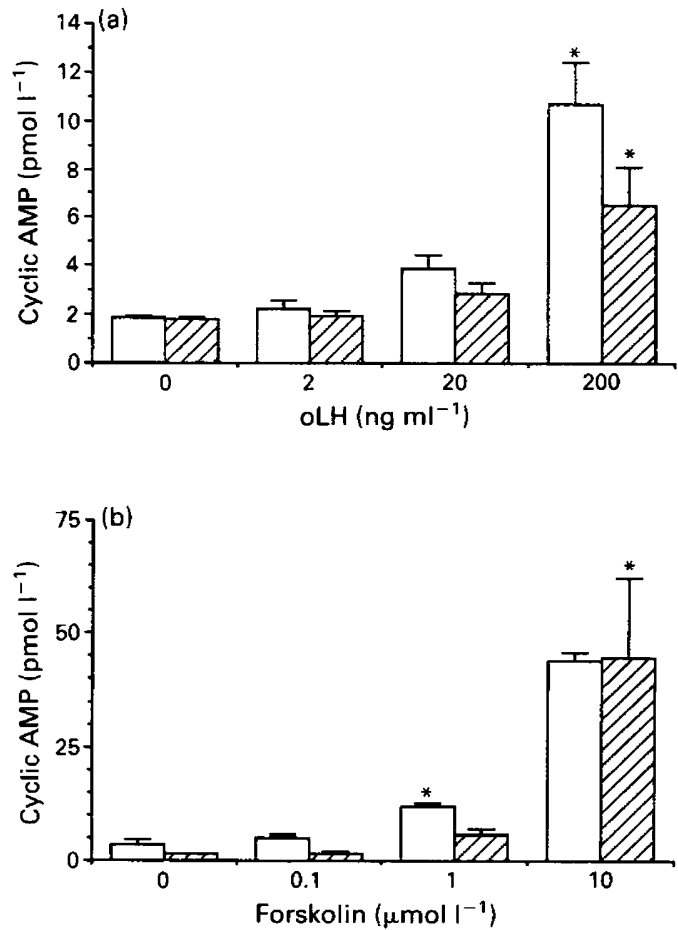

Fig. 3. Cyclic AMP accumulation in ovarian stromal cells from ( $\square$ ) pullets and ( $\bullet$ ) laying hens following incubation with (a) oLH and (b) forskolin in the presence of $0.1 \mathrm{mmol} 3$-isobutyl-1methylxanthine (IBMX) ${ }^{-1}$. Data represent the mean \pm SEM from four $(\mathrm{oLH})$ or three (forskolin) replicate experiments. ${ }^{*}$ Denotes the lowest stimulatory dose $(P<0.05$ vesus basal $)$.

production in MAT or IM cells. By contrast, PMA inhibited $\mathrm{oLH}$ - and 8-bromo-cAMP-induced androstenedione production in both cell types $(P<0.05$; Fig. 4$)$.

Although the ionophore A23187 failed to alter basal concentrations of androstenedione, there was a significant inhibitory effect of A23187 on oLH-induced androstenedione production by IM cells, MAT cells and $6-8 \mathrm{~mm}$ follicle theca cells (Fig. 5). As previously observed (Fig. 4), PMA inhibited oLH-induced androstenedione, while A23187 had a compounding, inhibitory effect on androstenedione production in the presence of PMA.

Finally, in an effort to compare the steroidogenic potential of these three tissues directly, it was determined that basal and $\mathrm{oLH}$-induced androstenedione production (in the absence of A23187 and PMA) was highest in theca cells from $6-8 \mathrm{~mm}$ follicles $(0.43 \pm 0.03 \mathrm{ng}$ and $9.90 \pm 2.58 \mathrm{ng}$, respectively; $P<0.05$ versus IM and MAT cells) (Fig. 5); consistent with results from experiment 1 , oLH-stimulated androstenedione production was greater in MAT cells $(2.17 \pm 0.21 \mathrm{ng})$ than in IM cells $(1.15 \pm 0.06 ; P<0.05)$.

\section{Experiment 5: effects of TGF- $a$ on steroidogenesis}

Neither TGF- $\alpha$ (18 pmol $\left.1^{-1}\right)$ nor EGF (164 nmol $\left.\mathrm{l}^{-1}\right)$ had an effect on basal progesterone or androstenedione production by IM cells (basal production was $10 \pm 5$ and $80 \pm 10 \mathrm{pg}$ for progesterone and androstenedione, 

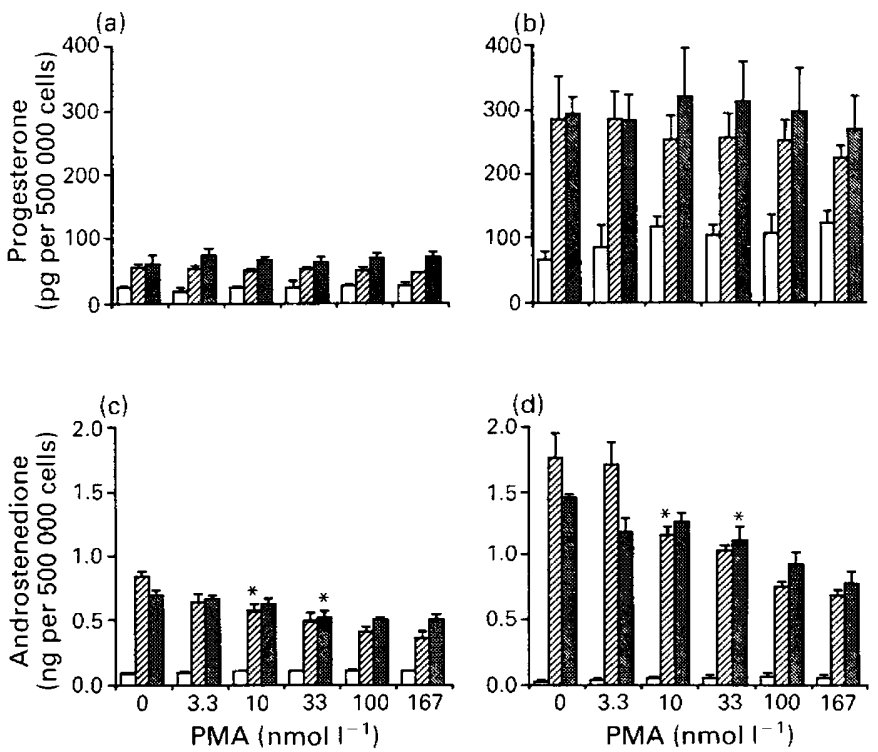

Fig. 4. Effects of PMA on ( $\square$ ) basal, ( $\square$ ) oLH- and (图) 8-bromo cAMP-induced progesterone ( $a$ and $b$ ) and androstenedione ( $c$ and $d$ ) production in pullet $(a$ and $c$ ) and laying hen ( $b$ and $d$ ) cells. Data are means \pm SEM of three replicate experiments. *Denotes the lowest inhibitory dose of PMA $(P<0.05$ versus agonist in absence of phorbol myristate 13-acetate (PMA).

respectively), MAT cells ( $23 \pm 22$ and $90 \pm 20$, respectively), 6-8 mm follicle theca cells ( $19 \pm 14$ and $210 \pm 70 \mathrm{pg}$, respectively) or F2 follicle theca cells (190 \pm 27 and $1950 \pm 580 \mathrm{pg}$, respectively) $(P>0.10)$. In addition, TGF- $\alpha$ and EGF failed to alter oLH-induced steroid production from IM cells $(72 \pm 9$ and $820 \pm 80 \mathrm{pg}$ for progesterone and androstenedione, respectively), MAT cells (205 \pm 47 and $3120 \pm 430 \mathrm{pg}$, respectively), $6-8 \mathrm{~mm}$ follicle theca cells $(119 \pm 19$ and $8070 \pm 2090 \mathrm{pg}$, respectively) or F2 follicle theca cells (1063 \pm 181 and $41530 \pm 15480 \mathrm{pg}$, respectively) $(P>0.10)$. Similarly, lower doses of TGF- $\alpha$ ( 1.8 and 6 pmol l$^{-1}$ ) and EGF (16 and $41 \mathrm{nmol} \mathrm{l}^{-1}$ ) had no effect on androstenedione production (data not shown).

\section{Discussion}

The most significant findings from the present studies are that while ovarian stromal tissue from both pre- and post-pubertal animals produces progestin, androgen and oestrogen, $\mathrm{LH}$-induced steroid production is greater in MAT than in IM cells and that stimulation and modulation of such steroid production occurs via cellular mechanisms similar to those that function within theca cells from $6-8 \mathrm{~mm}$ and preovulatory (F2) follicles. While Robinson and Etches (1986) concluded that whole follicles less than $1 \mathrm{~mm}$ in diameter collected from the laying hen ovary are steroidogenically active, they did not evaluate steroid production by ovarian stromal tissue, or speculate on the site of production (theca and/or granulosa tissue). Our results indicate that stromal cells from the laying hen (MAT cells) respond to LH. Moreover, the finding that dispersed IM cells produce progesterone, androstenedione and oestrogen is consistent with previous studies that used whole ovary incubations (Tanabe et al., 1979; Marrone, 1986; Pedernera et al., 1988).

The ability of oLH and forskolin to stimulate cAMP accumulation and steroid production, together with the ability of 8-bromo cAMP to mimic the effect of oLH, in both IM cells and MAT cells, indicate that the adenylyl cyclase/cyclic AMP second messenger pathway has a role in the regulation of steroidogenesis (Marrone, 1986). It is of interest, however, that whereas a dose of $2 \mathrm{ng} \mathrm{oLH} \mathrm{ml}{ }^{-1}$ stimulates steroid production from IM and MAT cells, a dose of $200 \mathrm{ng} \mathrm{oLH} \mathrm{ml}{ }^{-1}$ is required to detect a significant increase in cAMP accumulation. This observation is similar to that reported for F2 theca (Tilly and Johnson, 1989a) and for theca from 6-8 mm steroids (Kowalski et al., 1991). Such results may indicate that low doses of gonadotrophin may act via a cAMP-independent second messenger pathway such as the calcium-calmodulin system (Levorse et al., 1991). Alternatively, it is possible that low doses of oLH may induce significant increases in cAMP within localized subcellular compartments and that such changes are not detectable with measurements of whole cells.

Although oLH stimulates steroid production in both IM and MAT cells, it does so to a somewhat different degree; MAT cells produce more progesterone, androstenedione and oestradiol in response to oLH than do IM cells. It is unlikely that such differences in steroid production result from more functional LH receptors on MAT cells, as the accumulation of cAMP following oLH treatment in this study was not significantly different in IM versus MAT cells. Furthermore, the increase in cAMP accumulation following forskolin treatment is comparable, and responsiveness perhaps greater, in IM versus MAT cells, indicating competence of the post-receptor adenylyl 


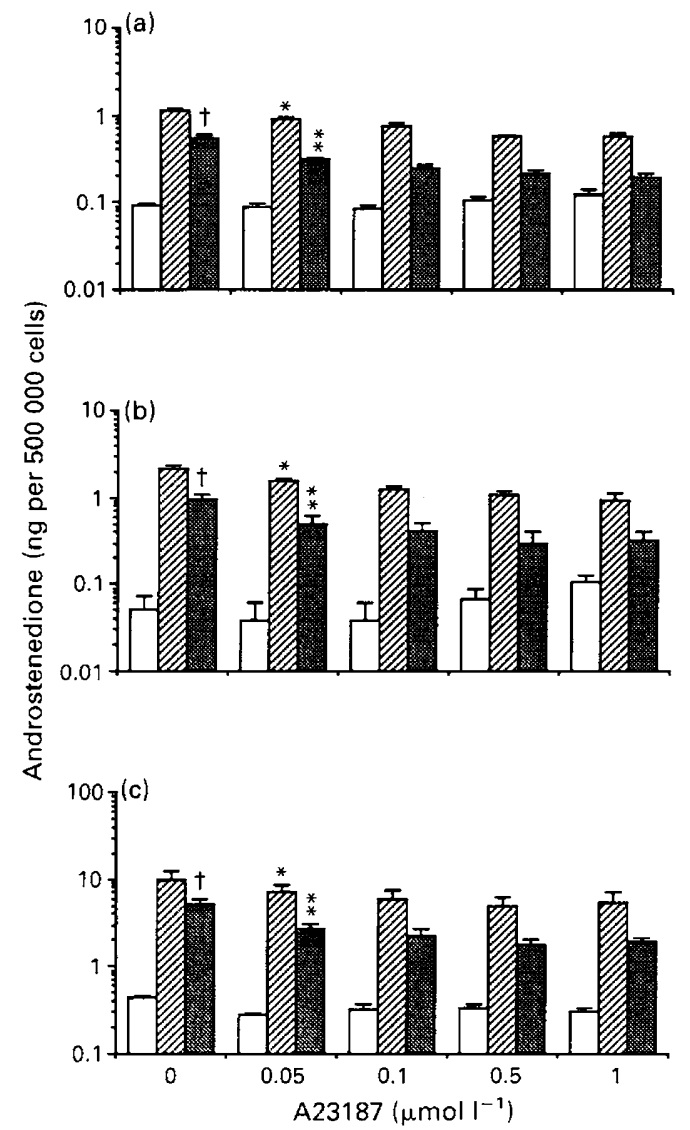

Fig. 5. The calcium ionophore A23187 failed to affect ( $\square$ ) basal androstenedione production by ovarian stromal cells from (a) pullets, (b) laying hens and (c) $6-8 \mathrm{~mm}$ follicle theca cells collected from laying hens. By contrast, A23187 inhibited oLH (20 $\mathrm{ng} \mathrm{ml}^{-1}$ )-stimulated androstenedione production ( $\square$; *denotes lowest inhibitory dose). Phorbol myristate 13-acetate (PMA) (167 nmol l${ }^{-1}$ ) inhibited oLHstimulated androstenedione production in the absence of A23187 $\left(P<0.05\right.$; denoted by $\left.{ }^{\dagger}\right)$, while A23187 had an additive, inhibitory effect in the presence of PMA (圆); ${ }^{* *}$ denotes lowest inhibitory dose versus absence of $A 23187 ; P<0.05)$. Data represent the mean \pm SEM of three (laying hens) or four (pullets and $6-8 \mathrm{~mm}$ follicle theca) replicate experiments.

cyclase complex in IM cells. Although at this time we cannot explain why progesterone production in response to 8-bromo cAMP was not different in MAT versus IM cells, it is evident that this agonist stimulates androstenedione to a greater extent in MAT cells than in IM cells. Thus, generally higher amounts of steroid production by MAT cells indicate greater cytochrome P450 side-chain cleavage (P450scc) activity, $3 \beta$-hydroxysteroid dehydrogenase activity, or cytochrome P450 17 $\alpha$-hydroxylase ( $\mathrm{P} 45017 \alpha-\mathrm{OH})$ activity, or alternatively, reflect a greater availability of cholesterol substrate for metabolism to progestin. It is possible that the greater potential for steroid production by MAT cells reflects a longer period of exposure to circulating gonadotrophins, and in particular, $\mathrm{FSH}$. FSH can increase P450scc and P450 $17 \alpha-\mathrm{OH}$ mRNA abundance and induce enzyme activity in hen granulosa cells ( $\mathrm{Li}$ and Johnson, 1993a, b).
Previously published studies of granulosa and theca cells prepared from preovulatory follicles have implicated the protein kinase $\mathrm{C}$ second messenger pathway in the regulation of ovarian steroidogenesis (Asem and Tsang, 1989; Tilly and Johnson, 1988, 1989a, b). For instance, in FI granulosa cells, PMA and the diacylglycerol analogue 1-oleoyl-2acetylglycerol $(\mathrm{OAG})$ attenuate agonist-induced progesterone and androstenedione production. This attenuation is mediated via the prevention of CAMP accumulation and by the inhibition of P450scc activity (Tilly and Johnson, 1988). By comparison, PMA stimulates progesterone and androstenedione production in theca cells from $6-8 \mathrm{~mm}$ and $\mathrm{F} 2$ follicles, and this stimulation occurs in the absence of a detectable increase in cAMP accumulation (Tilly and Johnson, 1989a; Kowalski et al., 1991). In contrast, PMA inhibits LH-induced androstenedione (but not progesterone) production in theca cells from $6-8 \mathrm{~mm}$ and F2 follicles, and this modulation occurs distal to the formation of cAMP, via the inhibition of $\mathrm{P} 45017 \alpha-\mathrm{OH}$ enzyme activity. In the present studies, there was no detectable increase in basal concentrations of progesterone or androstenedione from IM or MAT cells in response to PMA treatment. This lack of a detectable increase may be due to the inherently low basal concentrations of steroid production in IM and MAT cells. However, PMA was found to inhibit oLH- and 8-bromocAMP-stimulated androstenedione (and not progesterone) production from IM and MAT cells. These results indicate that, as previously determined for theca cells from $6-8 \mathrm{~mm}$ and $\mathrm{F} 2$ follicle theca cells, protein kinase $C$ activation in stromal tissue inhibits $\mathrm{P} 45017 \alpha-\mathrm{OH}$ activity, but not $\mathrm{P} 450$ scc activity.

The growth factors TGF- $\alpha$ and EGF inhibit LH-induced progesterone production in hen FI granulosa cells (Pulley and Marrone, 1986; Tilly and Johnson, 1990a). TGF- $\alpha$ and EGF were shown to block FSH-induced increases in $\mathrm{P} 450 \mathrm{scc}$ and P450 $17 \alpha-\mathrm{OH}$ mRNA and enzyme activity in granulosa cells from 6-8 mm follicles ( $\mathrm{Li}$ and Johnson, 1993a, b). It was proposed that some of the effects of these growth factors on granulosa cells may be mediated, at least in part, via activation of protein kinase C (Tilly and Johnson, 1990a). Although TGF- $\alpha$ and EGF have been found not to affect plasminogen activator activity in theca cells from preovulatory follicles (Tilly and Johnson, 1990b), the effects of these growth factors on theca cell steroidogenesis have, until now, not been evaluated. Results from the study reported here indicate that neither TGF- $\alpha$ nor EGF alter basal or LH-stimulated steroid production in theca cells or stromal tissue following a shortterm $(4 \mathrm{~h})$ incubation. On the basis of these data, we propose that neither TGF $-\alpha$ nor EGF activates the protein kinase C second messenger pathway in these cells, and that these growth factors do not play a role in modulating either steroid production or plasminogen activator activity in theca cells; this lack of effect by TGF- $\alpha$ and EGF in follicles cannot be attributed to the absence of EGF receptors, as both EGF receptor mRNA (Johnson, unpublished data) and immunoreactive EGF receptor protein (O. M. Onagbesan and M. Peddie, personal communication) have been identified within theca tissue.

Although IM and MAT cells have a lower capacity to produce androstenedione in response to oLH than do $6-8 \mathrm{~mm}$ follicle and F2 follicle theca cells, the mechanisms that regulate steroid production in stromal (IM and MAT) cells are similar to 
those reported for theca cells (Tilly and Johnson, 1989a; Kowalski et al., 1991; this study). Progestin and androgen synthesis in avian theca occurs within the theca interna, whereas oestrogens are produced from a discrete population of cells located within the theca externa (Porter et al., 1989; Nitta et al., 1991). By contrast, granulosa cells fail to express aromatase activity at any stage during development (Armstrong, 1984). In the study reported here, the observation that the cell population collected from the Percoll gradient produces oestradiol indicates that there are theca externa-like cells. Nevertheless, our criterion for selection of cells from the Percoll gradient was based on ability to produce androstenedione, and not oestradiol; in fact, the greatest number of oestradiol producing cells was eluted at a density of 1.065 (Levorse, 1992). Furthermore, it is possible that ovarian stromal tissue is the predominant, if not sole, source of oestrogen in the immature pullet. Finally, studies have shown that dispersed granulosa cells from follicles less than $8 \mathrm{~mm}$ in diameter do not produce progesterone or androstenedione, in vitro, owing to the absence of $\mathrm{P} 450 \mathrm{scc}$ and $\mathrm{P} 45017 \alpha-\mathrm{OH}$ activities (Tilly et al., 1991; Li and Johnson, 1993a, b). Taken collectively, these observations indicate that the steroidogenically active IM and MAT cells prepared from stromal tissue are of theca cell origin.

In agreement with results obtained using F2 theca cells (Levorse et al., 1991), A23187 had no effect on basal steroid production in IM cells, MAT cells or theca cells from 6-8 mm follicles. Moreover, A23187 inhibited oLH-stimulated androstenedione production in each cell type examined, and this inhibitory effect was enhanced in the presence of PMA (Levorse et al., 1991; this study). The inhibitory effects of A23187 in theca and stromal tissue are in contrast to the stimulatory effects on progesterone and androstenedione production from F1 granulosa tissue (Tilly and Johnson, 1988). As discussed with reference to $\mathrm{F} 2$ theca cells, there are several possible explanations for the inhibitory effects of A23187 on androstenedione production in theca and stromal tissue. For example, high concentrations of intracellular calcium activate protein kinase $\mathrm{C}$ (Ho et al., 1988), and the results reported here indicate that protein kinase $\mathrm{C}$ activation (using PMA) inhibits LH- and 8-bromo-cAMP-stimulated androstenedione production. Alternatively, Johnson et al. (1990) provided evidence that A23187 stimulates the release of arachidonic acid in F2 theca cells, and that arachidonic acid inhibits androstenedione production in F2 theca cells. Finally, it is possible that the ionophore causes a supraphysiological rise in intracellular calcium concentrations, which subsequently inhibits cellular function (White et al., 1989).

In summary, results from the present experiments demonstrate that dispersed cells from ovarian stromal tissue of both sexually immature and mature birds are steroidogenically active and responsive to the gonadotrophin, LH. On a per cell basis, theca cells from $6-8 \mathrm{~mm}$ and F2 follicles produce more steroid; nevertheless, considering the mass of stromal tissue present at both stages of ontogeny, it is possible that such tissue contributes significantly to the total steroidogenic output of the ovary. Finally, the qualitative and quantitative pattern of steroidogenesis, and the cellular mechanisms regulating steroid production in IM and MAT cells are similar to those in theca cells from growing and preovulatory follicles. We conclude that the steroidogenically active cellular component of ovarian stromal tissue is the progenitor of follicle theca cells.

This study was supported by USDA Grants 90-37240-5510 and 92-37203-7767, the Charles and Johanna Busch Memorial Fund at Rutgers, The State University of NJ, and the NJ Agricultural Experiment Station (Publication D-06109-03-93). Ovine LH was a gift from the National Institutes of Health. The authors thank C. Bynes for excellent technical assistance.

\section{References}

Armstrong DG (1984) Ovarian aromatase activity in the domestic fowl (Gallus domesticus) Journal of Endocrinology 100 81-86

Asem EK and Hertelendy F (1986a) Role of calcium in luteinizing hormoneinduced progesterone and cyclic AMP production in granulosa cells of the hen (Gallus domesticus) General and Comparative Endocrinology 62 120-128

Asem EK and Hertelendy F (1986b) Trifluoroperizine inhibits progesterone and cyclic AMP production in granulosa cells of the hen (Gallus domesticus) General and Comparative Endocrinology 64 107-111

Asem EK and Hertelendy F (1987) Trifluoroperizine inhibits ovarian mitochondrial side-chain cleavage enzyme activity in the absence of calcium Journal of Steroid Biochemistry 28 353-355

Asem EK and Tsang BK (1989) Phorbol ester inhibits luteinizing hormone-, forskolin-, and dibutyryl cyclic AMP-induced progesterone production in chicken granulosa cells Canadian Journal of Physiology and Pharmacology 67 $122-125$

Asem EK, Molnar M and Hertelendy F (1987) Luteinizing hormone-induced intracellular calcium mobilization in granulosa cells: comparison with forskolin and 8-bromo-adenosine $3^{\prime}, 5^{\prime}$-monophosphate Endocrinology 120 853-859

Ho AK, Thomas TP, Chik CL, Anderson WB and Klein DC (1988) Protein kinase C: subcellular redistribution by increased $\mathrm{Ca}^{2+}$ influx Joumal of Biological Chemistry $2639292-9297$

Johnson AL (1990) Steroidogenesis, and actions of steroids in the hen ovary. In CRC Critical Reviews in Poultry Biology, Vol. 2 pp 319-346 Ed. RR Dietert. CRC Press, Boca Raton

Johnson AL and Tilly JL (1988) Effects of vasoactive intestinal peptide on steroid secretion and plasminogen activator activity in granulosa cells of the hen Biology of Reproduction 38 296-303

Johnson AL, Tilly JL and Levorse JM (1990) Possible role for arachidonic acid in the control of steroidogenesis in hen theca Biology of Reproduction $\mathbf{4 4}$ 338-344

Kowalski KI, Tilly JL and Johnson AL (1991) Cytochrome P450 side-chain cleavage ( $\mathrm{P} 450 \mathrm{scc}$ ) in the hen ovary. I. Regulation of $\mathrm{P} 450 \mathrm{scc}$ messenger RNA levels in theca cells of developing follicles Biology of Reproduction 45 955-966

Levorse JM (1992) Regulation of Ovarian Theca Cell Steroidogenesis in the Domestic Hen during Follicle Development MS Thesis, Rutgers, The State University of New Jersey

Levorse JM, Tilly JL and Johnson AL (1991) Role of calcium in the regulation of theca cell androstenedione production in the domestic hen Journal of Reproduction and Fertility 92 159-167

Li $Z$ and Johnson AL (1993a) Regulation of P450 cholesterol side-chain cleavage messenger ribonucleic acid expression and progesterone production in hen granulosa cells Biology of Reproduction 49 1293-1302

Li Z and Johnson AL (1993b) Expression and regulation of cytochrome P450 $17 \alpha$-hydroxylase mRNA levels and androstenedione production in hen granulosa cells Biology of Reproduction 49 463-469

Marrone BL (1986) Ovarian steroidogenesis in vitro during the first month posthatching in the domestic chick: gonadotropin responsiveness and $\left[{ }^{3} \mathrm{H}\right]$ progesterone metabolism General and Comparative Endocrinology 62 62-69

Nitta H, Osawa I and Bahr JM (1991) Multiple steroidogenic cell populations in the thecal layer of preovulatory follicles of the chicken ovary Endocrinology 129 2033-2040

Pedernera E, Gomez Y, Velazquez P, Juarez-Dropeza MA and Gonzalez Del Pliego M (1988) Identification of steroidogenic cell subpopulations in the ovary of the newly hatched chicken General and Comparative Endocrinology $\mathbf{7 1}$ 153-162 
Porter TE, Hargis BM, Silsby JL and El Halawani ME (1989) Differential steroid production between theca interna and theca externa cells: a three-cell model for follicular steroidogenesis in avian species Endocrinology 125 109-116

Pulley DD and Marrone BL (1986) Inhibitory action of epidermal growth factor on progesterone biosynthesis in hen granulosa cells during short term culture: two sites of action Endocrinology 118 2284-2291

Robinson FE and Etches RJ (1986) Ovarian steroidogenesis during follicular maturation in the domestic fowl (Gallus domesticus) Biology of Reproduction 35 1096-1105

Tanabe Y, Nakamura T, Fujioka K and Doi $O$ (1979) Production and secretion of sex steroid hormones by the testes, the ovary and the adrenal glands of embryonic and young chickens (Gallus domesticus) General and Comparative Endocrinology $3926-33$

Tilly JL and Johnson AL (1987) Presence and hormonal control of plasminogen activator in granulosa cells of the domestic hen Biology of Reproduction 37 $1156-1164$

Tilly JL and Johnson AL (1988) Attenuation of hen granulosa cell steroidogenesis by a phorbol ester and 1-oleoyl-2-acetylglycerol Biology of Reproduction 39 1-8

Tilly IL and Johnson AL (1989a) Regulation of androstenedione production by adenosine $3{ }^{\prime} 5$ '-monophosphate and phorbol myristate acetate in ovarian thecal cells of the domestic hen Endocrinology 125 1691-1699
Tilly JL and Johnson AL (1989b) Mechanisms by which a phorbol ester and a diacylglycerol analog inhibit hen granulosa cell steroidogenesis Domestic Animal Endocrinology 6 155-166

Tilly JL and Johnson AL (1990a) Modulation of hen granulosa cell steroidogenesis and plasminogen activator activity by transforming growth factor alpha Growth Factors 3 247-255

Tilly JL and Johnson AL (1990b) Effect of several growth factors on plasminogen activator activity in granulosa and theca cells of the domestic hen Poultry Science $69292-299$

Tilly JL, Kowalski KI and Johnson AL (1991) Stage of ovarian follicular development associated with the initiation of steroidogenic competence in avian granulosa cells Biology of Reproduction 44 305-314

White BA, Power E and Fay FS (1989) Calcium regulation of prolactin gene expression: opposing effects of extracellular $\mathrm{CaCl}_{2}$ and $\mathrm{Ca}^{2+}$ ionophores Molecular Endocrinology 13 1757-1764

Zakar T and Hertelendy F (1980) Steroidogenesis in avian granulosa cells: early and late kinetics of oLH-and dibutyryl cyclic AMP-promoted progesterone production Biology of Reproduction 23 974-980 